\title{
Assessment of serum Zinc, Copper and Selenium in non- symptomatic Sickle-Cell Anaemia patients at the University Teaching Hospital, Lusaka, Zambia
}

\author{
Alfred Machiko $^{1^{*}(\mathbb{D})}$, Trevor Kaile ${ }^{2}$, Sumbukeni Kowa $^{3}$, Christopher Newton Phiri ${ }^{2}$, Jacob Ndhlovu $^{2}$, Marah \\ Simakando ${ }^{2}$, Soka Nyirenda ${ }^{4}$ \\ ${ }^{1}$ Copperbelt University, Michael Chilufya Sata School of Medicine, P.O. BOX 71191, Hillcrest Ndola, Zambia, ${ }^{2}$ University of Zambia, \\ School of Medicine, Department of Pathology and Microbiology, ${ }^{3}$ Ministry of Health, Food and Drugs Control Laboratory, Lusaka, Zambia, \\ ${ }^{4}$ Ministry of Health, University Teaching Hospital, Lusaka, Zambia.
}

*Corresponding author: machikoalfred@gmail.com

\section{Abstract}

To cite: Machiko A, Kaile T, Kowa S, Newton Phiri CN, Ndhlovu J, Simakando M, Nyirenda S Assessment of serum Zinc, Copper and Selenium in non-symptomatic Sickle-Cell Anaemia patients at the University Teaching Hospital, Lusaka, Zambia. JPRM 2021,3(2): 69-74. doi: $10.21617 /$ jprm2021.3212

Background: Zinc, copper and selenium are known important trace elements playing a vital role as cofactors of enzymes such as superoxide dismutase and glutathione peroxide. They form part of the first line antioxidants enzymes in red blood cells and plasma. The study aimed at determining the serum levels of zinc, copper and selenium in asymptomatic sickle-cell anaemia patients.

Methods: This was a case control study conducted from the specialist Haematology and Oncology Clinic 4 at the University Teaching Hospital, Lusaka, Zambia. $5 \mathrm{mls}$ of whole blood was collected from 46 sickle-cell anaemia patients and 46 healthy controls from Out-Patient Department after consent. Using Atomic Absorption Spectrometry, serum levels of zinc, copper and selenium was determined. Independent t-test was used to compare the means and a binary logistic regression for the likelihood of developing a sickling crisis, using SPSS version 20 .

Results: The mean serum levels of zinc in patients were lower $86.92 \pm 20.46 \mathrm{mg} / \mathrm{L}$ against $91.33 \pm 43.23 \mathrm{mg} / \mathrm{L}$; $\mathrm{p}<0.028$ of controls. Copper mean levels were $149.85 \pm 54.82 \mathrm{mg} / \mathrm{L}$ against $134.32 \pm 54.16 \mathrm{mg} / \mathrm{L} ; \mathrm{p}<0.191$ of controls. Selenium mean levels were $0.100 \pm 0.041 \mathrm{mg} / \mathrm{L}$ against $0.081 \pm 0.032 \mathrm{mg} / \mathrm{L} ; \mathrm{p}<0.380$ in patients compared to controls. The odds of developing one sickling crises in the past year given the levels of zinc, copper and selenium was $[B=-.340$, zinc $\operatorname{Exp}(B)=1.011$, copper $\operatorname{Exp}(B)=1.008$, selenium $\operatorname{Exp}(B)=.000, D F$ $=1]$.

Conclusion: Zinc is reduced in sickle-cell anaemia patients. The probability of developing a sickling crisis is lower in patients with higher serum levels of zinc and copper by $1.1 \%$ and $0.8 \%$ respectively.

Keywords: Sickle-cell anaemia, Zinc, Copper, Selenium, Antioxidants 


\section{INTRODUCTION}

Sickle-Cell Anaemia (SCA) is one of the commonly inherited monogenic disorder in Arabian Gulf countries, India, the Caribbean and Africa [1]. In Africa, prevalence of the sickle-cell trait stands at around 5\% to 30\% [2]. In Zambia, the prevalence of the sickle-cell trait is $6 \%$ to $27 \%$ of the population [3]. Sickle-cell anaemia is characterised by the inheritance of a mutated $\beta$-globin chain at position 6 where Valine is substituted for Glutamic acid there by changing the biochemical properties of the beta chain with devastating consequences [4]. These changes lead to instability of the generated haemoglobin or to globin chain imbalance, impacting on the oxidative environment both intracellular and extracellular. The ensuing oxidative stress and the inability of the body to adequately overcome it are responsible for the pathophysiology of the disease [5]. Reactive Oxygen Species can be grossly amplified in response to a variety of pathophysiological conditions such as hypoxia, inflammation, infection, dehydration and deficiency in trace minerals and antioxidant vitamins [6].

Zinc, copper and selenium are trace elements vital in blood as components of first line antioxidant enzymes such as superoxide dismutase, glutathione peroxidase and catalase [7] [8] $[9,10]$. Deficiency of zinc, copper and selenium in sickle-cell anaemia is documented in parts of west and central Africa [11] [12]. However, no similar studies have been conducted and published on the levels of these trace elements in Zambia in particular, in sicklecell anaemia patients. This study further tries to find a likelihood of developing one sickling crises per year given the serum levels of zinc, copper and selenium in sickle-cell anaemia patients.

\section{METHODS AND MATERIALS}

This study was conducted on known patients with homozygous sickle-cell anaemia ( $\mathrm{HbSS}$ ), diagnosed by physicians using $\mathrm{Hb}$ electrophoresis. The study patients and controls had the similar socio-economic status and dietary habits. The study was a case control study with sequential recruitment of study participants with sickle-cell anaemia and those without the disease. A total of 46 sickle-cell anaemia patients (mean age 18.11 $\pm 9.253 \mathrm{yrs}$ ) (Figure 1) and a sex distribution of 26.06 males and 73.91 females (Figure 2). A total of 46 healthy controls (mean age 18.52 $\pm 9.254 \mathrm{yrs}$ ) (Figure 3) and a sex distribution of 23.91 males and 76.09 females
(Figure 4) were recruited for this study from the University Teaching Hospital, Haematology $\neg$ ᄀ and Oncology clinic 4, Lusaka province after obtaining ethical clearance from the University of Zambia Biomedical and Research Ethics Committee (UNZABREC) and appropriate informed consent from the subjects as well as their parents/guardian. The recruited participants were matched for age and sex. $5 \mathrm{mls}$ of venous blood samples were collected from each participant into a plain container. The labelled samples were spun in a bucket centrifuge at a speed of $4000 \mathrm{rpm}$ for 3 minutes to separate serum from red blood cells. The serum obtained was stored in a chest freezer at a temperature of $-20 \mathrm{o}$ $\mathrm{C}$ until the day of testing. Serum trace element levels were determined by atomic absorption spectrophotometer (Contra AA700® ANELYTIK JENA, Germany) using the technique as described by Al-Assaf [13]. Analytical reagent grade chemicals, standards were used. Water used for washing laboratory apparatus and for preparing solutions and standards was purified by deionization of distilled water using Milli-Q system (Millipore, Bedford, USA). Statistical analysis was performed by using SPSS version 20.0 for windows. Firstly, we plotted the data on the Q-Q plot and tested them for normality. The results suggested that the distribution of our data sets was normally distributed thus, the results were expressed as mean $\pm \mathrm{SD}$ and a $\mathrm{P}$ value of $<0.05$ was considered significant. Binary logistic regression was used to find the likelihood of developing one sickling crises in the past year given the levels of zinc, copper and selenium in sickle cell anaemia patients

\section{RESULTS}

Serum levels of zinc were significantly lower in sickle-cell anaemia compared to healthy individuals (Figure 5), Serum copper levels though elevated and selenium levels though lower were not statistically significant between asymptomatic sickle-cell anaemia patients and healthy normal individuals (Figure 6), (Table 1). The odds of developing a sickling crisis was lower in sickle cell anaemia patients with higher serum levels of zinc and copper by $1.1 \%$ and $0.8 \%$ respectively in the previous year (Table 2). 


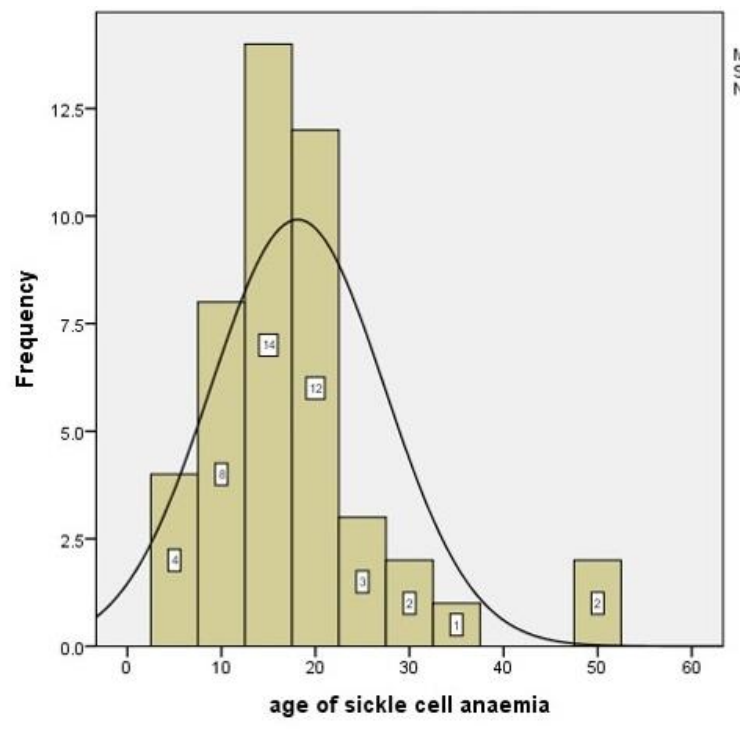

Figure 1: Sex distribution of sickle cell anaemia patients

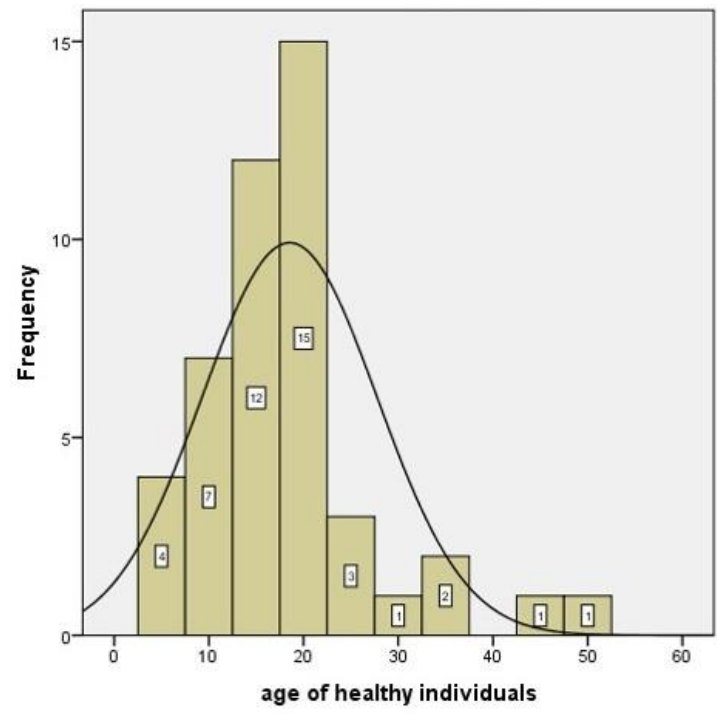

Figure 2: Age distribution of health control individuals

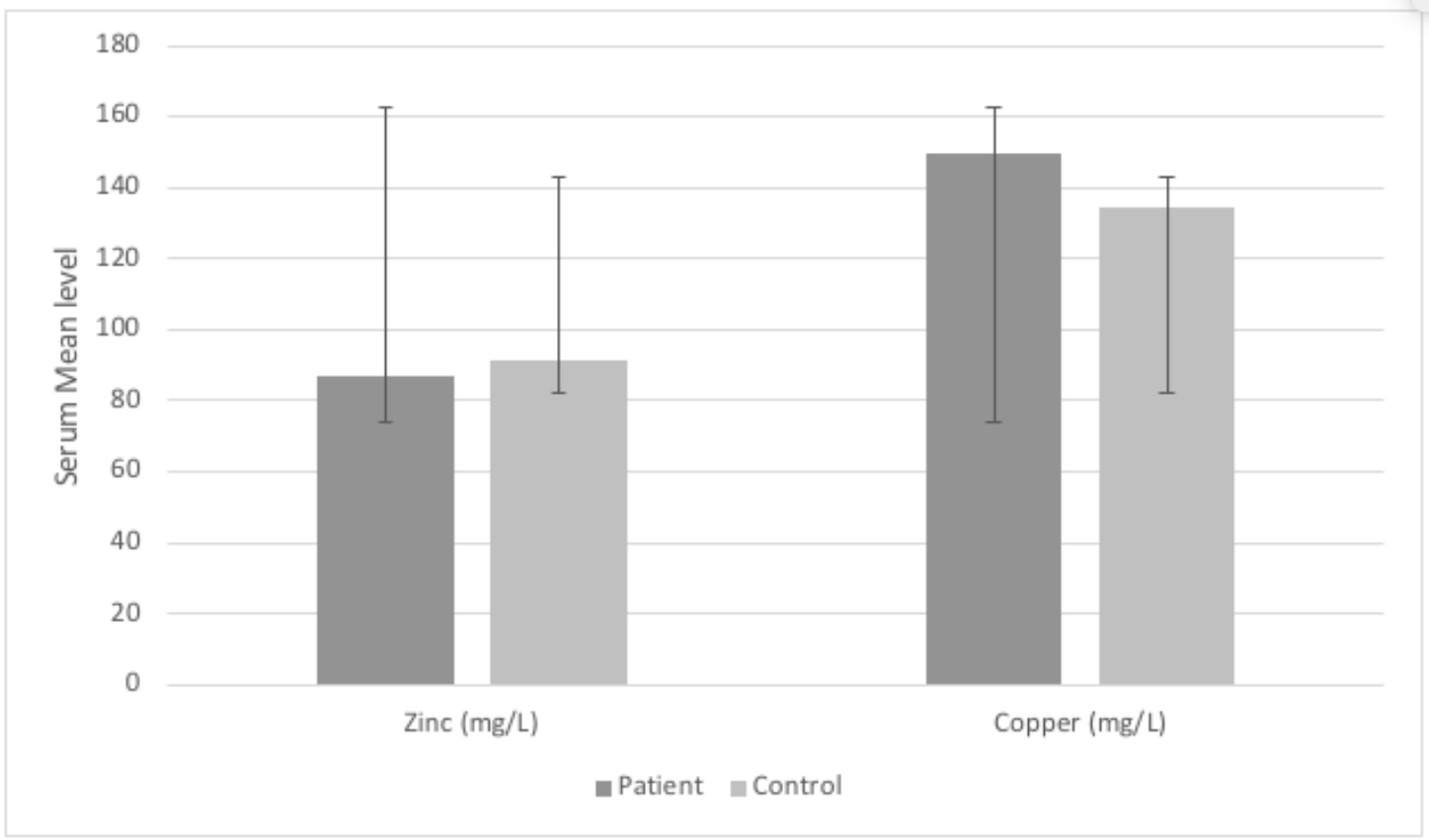

Figure 3: Shows the serum mean levels of Zinc and Copper and Standard Deviation 
Machiko A, Kaile T, Kowa S, Newton Phiri CN, Ndhlovu J, Simakando M, Nyirenda S Assessment of serum Zinc, Copper and Selenium in non-symptomatic Sickle-Cell Anaemia patients at the University Teaching Hospital, Lusaka, Zambia

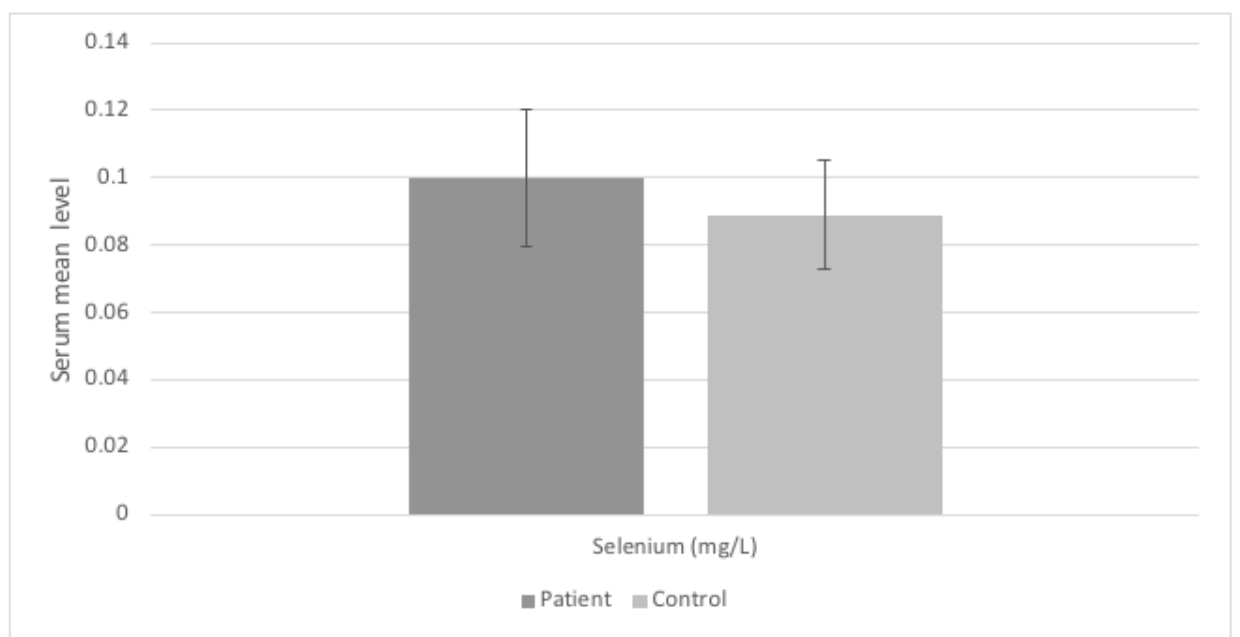

Figure 4: Shows the serum mean level Selenium and Standard Deviation

Table 1: Shows the mean serum levels of zinc, copper and selenium, standard deviation and the P-values.

\begin{tabular}{lccc}
\hline Variable & Patient Group & Control Group & P-Value \\
\hline Zinc(mg/L) & $86.92 \pm 20.46$ & $91.33 \pm 43.23$ & 0.028 \\
Copper(mg/L) & $149.85 \pm 54.82$ & $134.32 \pm 54.16$ & 0.191 \\
Selenium(mg/L) & $0.100 \pm 0.041$ & $0.081 \pm 0.0382$ & 0.380 \\
\hline \hline Number & 46 & 46 & \\
\hline
\end{tabular}

Table 2: Shows an SPSS output of coefficients showing the odds ratio. The odds show that a decrease in serum levels of zinc and copper will increase the probability of developing a sickling crises by $1.1 \%$ and $0.8 \%$ respectively.

\begin{tabular}{|c|c|c|c|c|c|c|c|}
\hline \multicolumn{8}{|c|}{ variadies in the Equauon } \\
\hline & & B & S.E. & Wald & df & Siq. & $\operatorname{Exp}(B)$ \\
\hline \multirow{4}{*}{ Step $1^{a}$} & zinc & .011 & .019 & .376 & 1 & .540 & 1.011 \\
\hline & Copper & .008 & .008 & 1.197 & 1 & .274 & 1.008 \\
\hline & selenium & -11.198 & 8.645 & 1.678 & 1 & .195 & .000 \\
\hline & Constant & -.340 & 1.570 & .047 & 1 & .829 & .712 \\
\hline
\end{tabular}

a. Variable(s) entered on step 1: zinc, Copper, selenium. 


\section{DISCUSSION}

In our study the age distribution of sickle cell anaemia patients shared a mean age of $(18.11 \pm 9.2 \mathrm{yrs})$ and the healthy controls mean age was (18.52 $\pm 9.6 y r s)$. This is inconsistent with data reported by Barclay et al. [14] who reported the mean age in Zambian sickle cell anaemia patients to be below 13 years. This increase in mean age in sickle cell anaemia patients can be attributed to improved patient management and health education in sickle cell anaemia patients over the years. With regards to sex distribution, $26.09 \%$ of sickle cell anaemia patients were male compared to $73.91 \%$ females.

The present study indicated a reduction in mean serum zinc in sickle-cell anaemia patients compared to healthy individuals. Sickle-cell anaemia patients despite having a normal diet have inadequate zinc intake due to chronic pain, haemolysis and reduced appetite. These patients have increased demand and consumption for zinc which may result in zinc deficiency. Further reason for zinc deficiency is increased urinary excretion due to impaired renal function and hypoxanthinuria which is common in sickle cell anaemia patients $[15,16]$. Our findings may suggest an imbalanced redox internal environment and increased oxidative stress which may complicate the severity of the sickling crises [17]. Our findings agree with several other studies [18]. A study by Hasanato [19] involving 25 sickle cell anaemia patients and 25 controls found reduced levels of zinc and antioxidant vitamins A, $\mathrm{C}$ and $\mathrm{E}$. The present study showed that patients with higher serum zinc had reduced the odds of having a sickling crisis by $1.1 \%$. This is because zinc is important in the maturation and function of $\mathrm{B}$ and $\mathrm{T}$ lymphocytes and in the normal function of natural killer cells and neutrophils [20]. Zinc is needed for DNA synthesis and RNA transcription, cell division and cell activation and forms part of the first line antioxidant defense enzymes superoxide dismutase (SOD). With these functions, Zinc deficiency adversely affects the secretion and functions of cytokines, the basic messengers of the immune system [20]. Though no evidence link zinc directly to the sickling crises, its function does and this may explain why increased zinc levels lowers the odds of developing a sickle cell crisis.

Mean copper serum levels in the present study were elevated in sickle cell anaemia patients compared to healthy individuals though there was no statistical difference between the two groups. Copper is part of the enzyme Superoxide
Dismutase $(\mathrm{Cu} / \mathrm{ZnSOD})$ and play an important role in Ceruloplasmin which helps in Iron metabolism and haemopoiesis [21]. Though it plays many physiological roles it has been found to be significantly raised in many other conditions such as chronic obstructive pulmonary disease (COPD), malignancy and psychosis [22]. This is because copper is a pro-oxidant metal sometimes known for producing unpaired electrons and increased levels lead to increased oxidative stress and this may further increase the severity of a sickling process [8]. Zinc competes with copper for binding sites on proteins thus, increased copper levels previously observed is a result of zinc deficiency observed in sickle-cell anaemia patients [21, 23]. A study conducted in Sudan showed an increase in copper levels in homozygous sickle-cell patients which affirms our results [12]. Another study by Hasanato had similar significantly raised copper serum levels [19]. The present study shows that patients with higher serum copper had reduced odds of developing a sickling crisis by $0.8 \%$.

In the present study there was no statistical difference between the two groups in mean serum selenium. Selenium is an important microelement in the antioxidant enzymes like glutathione peroxidase [24]. This enzyme is cardinal as it helps reduce the increased oxidative stress observed in sickle-cell anaemia patients due to excessive oxygen radicals. Our logistic model showed zero probability of selenium reducing chances of developing a sickling crisis and this may be due to variability of our data sets. A study done Sudan involving 70 sickle cell anaemia and 30 controls showed a significant reduction in the serum levels of selenium in sickle-cell anaemia patients compared to controls while another study done in India showed significant reduction of Selenium in oesophageal carcinoma $[12,22]$.

\section{CONCLUSION}

Our study showed a markedly reduced zinc concentration in sickle-cell anaemia patients compared to health normal individuals. In contrast we observed a relatively high mean serum copper in our sickle cell anaemia patients than controls. These results tend to indicate that the probability of our sickle cell anaemia patients developing a sickle cell crisis was $1.1 \%$ for mean zinc levels and $0.8 \%$ for mean copper levels observed. Selenium serum concentration did not contribute to the development of sickle cell crisis. What is already know on this topic

- Zinc is increased in sickle-cell anaemia 
- $\quad$ Increased serum copper and reduced serum selenium in sickle-cell anaemia

- $\quad$ Precipitating factors for a sickling crisis What this study adds

- $\quad$ Serum levels of zinc, copper and selenium in Zambian sickle-cell anaemia patients

- $\quad$ Likelihood/odds of developing a sickling crisis in sickle cell anaemia patients given the serum levels of zinc, copper and selenium.

Competing interests.

\section{DECLARATION}

Contributors AM developed the concept in close guidance with SN. All authors have read and approved the final version of the manuscript.

Competing interests There were no competing interests from all authors in this study.

Acknowledgements we would like to thank you Lusaka Apex Medical University for the Scholarship and the University Teaching Hospital for allowing us to conduct the research from the hospital.

\section{REFERENCES}

1.Elamin Abdelaziz. Current Trends in the Management of Sickle Cell Disease: Review Article. Sudan JMS. 2007; 2(2): 129-138.

2.World Health Organisation. Fifty-ninth World Health Assembly: Sickle Cell Anaemia. Report of the Secretariat. 2006; A59/9: 1-5.

3.Grosse D Scott, Odame Isaac, Atrash K Hani, Djesika D Amendah, Piel B Frederic, Williams N Thomas. Sickle cell disease in Africa: a neglected cause of early childhood mortality. Am J Prev Med. 2011; 41(6):398-405.

4.Queiroz Rapheal Ferreira, Lima Emerson Silva. Oxidative stress in sickle cell disease. Revista brasileira de hematologia e hemoterapia. 2013; 35(1): 16-17.

5. Voskou S, Aslan M, Fanis P, Phylactides M, Kleanthous M. Oxidative stress in $\beta$-thalassaemia and sickle cell disease. Redox biology. 2015; 6:226-239.

6. Kaur M, Dangi CBS, Singh M. An overview on sickle cell disease profile. Research Journal of Biotechnology. 2013; 6(1) : 25-37.

7.Ho Emily. Zinc deficiency, DNA damage and cancer risk. Journal of nutritional biochemistry, 2004; 15(10): 572-578.

8. Mahabir Somdat, Splitz R Margaret, Barrera L Stephanie, Beaver Shao Hua, Etzel Carol, Forman R Michele. Int. J. Cancer. 2007; 120(5): 1108-1115.

9. Klotz L, kronke K, Buchczyk P, Sies H. Role of copper, zinc, selenium and tellurium in the cellular defense against oxidative and nitrosative stress. J. Nutr. 2003; 133(5): 1448-1451.

10. Rajeswari S, Swaminathan S. Role of copper in health and diseases. Int J Curr Sci. 2014; 10: 94-107.

11. Okochi V, Okpuzor J. Micronutrients as therapeutic tools in the management of sickle cell disease, malaria and diabetes. African Journal of biotechnology. 2005; 4(13): 1568-1579.

12. Khalid A Abobaker, Idris F Omer. Assessment of Renal Function Tests, copper and selenium levels in Homozygous Sickle
Cell Disease Patients at Aljazeera state in Sudan. Br J Med Health Res. 2015; 2(6): 46-51.

13.Al-Assaf A Nahla. Determination of serum trace elements Magnesium, Copper, Zinc, and Selenium in Asthmatic Patients by Atomic Absorption Spectrophotometry. Journal of Al - Nahrain University. 2010; 13(1): 20 - 25.

14. Barclay GP, Huntsman RG, Robb A. Population screening of young children for sickle cell anaemia in Zambia. Trans R Soc Trop Med Hyg. 1970; 64(5): 733-739.

15. Arruda M Martha, Mecabo Grazielle, Celso A Rodrigues, Matsuda S Sandra, Rabelo B Iara, Figueiredos Maria. Antioxidant vitamins $C$ and $E$ supplementation increases markers of haemolysis in sickle cell anaemia patients: a randomized, double - blind, placebo - controlled trial. British journal of haematology. 2013; 160(5): 688-700.

16. Wood C Katherine, Granger D Neil. Sickle cell disease: role of reactive oxygen and nitrogen metabolites. Clinical and experimental pharmacology and physiology. 2007; 34(9): 926-932.

17. Emokpae Abiodium Mathias, Ojiefo Uadia Patrick, Aisha Kuliya-Gwarzo. Antioxidant enzymes and acute phase proteins correlate with marker of lipid peroxide in adult Nigerian sickle cell disease patients. Iranian Journal of Basic Medical Sciences. 2010. 13(4): 177-182.

18. Rashidi Mohammadreza, Aboomardani Maryam, Rafraf Maryam, Arefhosseni Seyed-Rafie, Keshtkar Abbasali, Joshaghani Hamidreza. Effects of Vitamin E and Zinc Supplementation on Antioxidants in Beta-Thalassemia Major Patients. Iran J. Pediatr. 2011; 21(1): 8-14.

19. Hasanato MW Rana. Zinc and antioxidant vitamin deficiency in patients with severe sickle cell anemia. Ann Saudi Med. 2006; 26(1): 17-21.

20. Osredkar Josko, Sustar Natasa. Copper and zinc, biological role and significance of copper/zinc imbalance. J Clinic Toxicology. 2011; 3(1): 1-28.

21. Prasad S Ananda. Zinc: role in immunity, oxidative stress and chronic inflammation. Current Opinion in Clinical Nutrition and Metabolic Care. 2009; 12(6): 646-652.

22. Goyal MM, Kalwar AK, Vyas RK, Bhati A. A study of serum zinc, selenium and copper levels in carcinoma of esophagus patients. Indian Journal of Clinical Biochemistry. 2006; 21(1): 208210.

23. Prashanth L, Rattapagari KK, Chitturi RT, Baddam VR, Prasad LK. A review on role of essential trace elements in health and disease. Journal of Dr. NTR University of Health Sciences. 2015; 4(2): 75-85.

24. Zhao Hai-Wen, Lin jie, Wang xue-Bao, Cheng Xing, Wang Jian-Yong, Hu Bei-Lei, Zhang Xiong, Zhu Jian-Hong. Assessing plasma levels of selenium, copper, iron and zinc in patients of Parkinson's disease. PloS one. 2013; 8(12): 1-10. 